Araştırma

\title{
0-5 Yaş Çocuklarda Rotavirüs Sıklığı ve Anne-Babaların Rotavirüse Yönelik Bilgi Düzeyleri ve Uygulamaları
}

\author{
Tülay KUZLU AYYILDIZ*, Hülya KULAKÇI ALTINTAŞ**, Cansu AYDIN****, Esra MINAZ****, Tuğba YÖRÜK******
}

$\ddot{O} z$

Amaç: Bu çalışma, Zonguldak il merkezinde yaşayan 0-5 yaş arası çocuklarda rotavirüs sıklığını, anne-babaların rotavirüse yönelik bilgi düzeylerini ve uygulamalarını belirlemek amacıyla yapılmıştır. Yöntem: Çalışma kesitsel tanımlayıcı tipte bir araştırmadır. Çalışma, Mart 2019-Mayıs 2019 tarihleri arasında 354 anne-baba ile gerçekleştirilmiştir. Verilerin değerlendirilmesinde aritmetik ortalama, standart sapma, ortanca, minimum-maximum, yüzde-sayı değerleri ve ki kare testi kullanılmıştır. Bulgular: Çalışmada, anne babaların \%15.5'i çocuklarının rotavirüs ile karşılaştığını ifade etmiştir. Anne-babaların \%57.6'sının rotavirüs enfeksiyonunu, \%51.1'inin rotavirüs aşısını bildiği belirlenmiştir. Ailelerin rotavirüs aşısı yaptırmama nedenleri arasında aşıyı duymama ve maddi olanaksızlıklar yer almaktadır. Sonuç: Çalışmada, anne-babaların rotavirüs aşısını bilme oranının yüksek olmasına rağmen, rotavirüs aşısı yaptırma oranının düşük olduğu tespit edilmiştir. Annelerin eğitim düzeyi arttıkça rotavirüs aşısını yaptırma oranlarının arttı̆̆ belirlenmiştir.

Anahtar Kelimeler: Bilgi Düzeyi, Rotavirüs, Rotavirüs Aşısı.

\section{Abstract
The Incidence of Rotavirus in 0-5 Years Old Children and Parents' Knowledge Levels and Applications for Rotavirus}

Objective: The aim of this study was to determine the incidence of rotavirus in 0-5 children living in the city center in Zonguldak, and to determine the parents' knowledge levels and applications for rotavirus. Methods: This study was a descriptive cross-sectional research. The study was conducted with 354 parents between March 2019 and May 2019. Arithmetic mean, standard deviation, median, minimummaximum, percentage-number values and chi square test were used to data analysing. Results: In the study, $15.5 \%$ of the parents who stated that their children encountered rotavirus. It was determined that $57.6 \%$ of the parents knew rotavirus, and $51.1 \%$ of them were aware of rotavirus vaccine. The reasons why parents did not receive rotavirüs vaccine include not hearing the rotavirus vaccine and financial impossibility. Conclusion: In the study, although parents had a high knowledge of the rotavirus vaccine the rate of rotavirus vaccination was low. It was determined that the rate of having their child given rotavirus vaccine increased as mothers' education level increased $(p>.05)$.

Keywords: Level of Knowledge, Rotavirüs, Rotavirüs Vaccine.

Geliş tarihi: 25.05.2019 Kabul tarihi: 19.05.2020

$\dot{\mathrm{I}}$ shal günlük dışkı miktarının, sayısının ve sıvı içeriğinin artmasıdır. Anne sütü ile beslenen bebeklerde her zamankinden daha sık ve daha sulu dışkılama olarak tanımlamaktadır $(1,2)$. Akut gastroenteritler çocuklarda mortalite ve morbiditenin en s1k nedenlerinden olup, tüm dünyada ve ülkemizde önemli bir sağlık sorunudur (3). Dünya Sağlık Örgütü (2015) beş yaş altı çocuklarda, \%9 oranında ölüm nedeninin gastroenterit olduğunu ifade etmektedir (4). Çocuklarda görülen gastroenteritlerin en önemli nedenlerinden biri rotavirüs enfeksiyonlarıdır. Çocukların büyük çoğunluğu ilk beş yıl içinde en az bir kez rotavirüsle enfekte olmaktadır. Rotavirüs gastroenteritlerinin en s1k 6-24 ay arasında görülmekte olduğu, 1rk ve cinsiyete göre farklılık göstermediği bildirilmiştir $(5,6)$. Anne sütü ile beslenen çocuklarda hastalığın ciddiyeti ve süresinin az olduğu bildirilmiştir (7). Şafak (2014), 0-6 yaş çocuklarda, dışkı örneklerinde rotavirüsü incelediği prevalans çalışmasında; rotavirüs pozitifliği, 0-12 aylık çocuklarda \%9.1, 13-24 aylık çocuklarda \%16, 25-36 aylık çocuklarda \%21.7, 37-48 aylık çocuklarda \%20, 49-60 aylık çocuklarda \%13 ve >60 aylık çocuklarda \%6.6 olarak saptamıştır (8). Rotavirüse bağlı gastroenteritlerin çocuklarda kolay bulaşa sahip olması nedeniyle, özellikle hastanede yatan çocuklarda nozokomiyal yayılım yaygındır. Oral fekal yolla bulaştığı için gıda kaynaklı bulaşma hastalığın en önemli etiyolojik faktörü olarak görülmektedir. Enfeksiyonunun özellikle sonbahar ve kış mevsimlerinde görülme oranı artmaktadır (9). Rotavirüse bağlı gastroenteritlerde, çocuklarda sıvı volüm eksikliğine bağlı dehidratasyon belirti ve bulguları görülmektedir. Bunlar çocuklarda enerji kaybına, halsizliğe, iştahsızlığa ve ciddi metabolik sorunlara neden olabilmektedir. Bu nedenle anne-babaların rotavirüs hakkında bilgi düzeyleri değerlendirilmeli ve uygun girişimler planlanmalıdır (10). Rotavirüs enfeksiyonunun önlenmesinde aşı uygulaması önemlidir. Rotavirüs aşıları sıvı formdadır ve oral yoldan uygulanır. Ülkemizde uygulanan iki marka rotavirüs aşısı bulunmaktadır. Bebeklere, uygulanan aşıya bağlı olarak ikinci ve dördüncü aylarda iki doz ya da ikinci, dördüncü ve altıncı aylarda üç doz olarak uygulanmaktadır (11). Aşının, ilk dozunun 14 hafta +6 güne kadar son dozunun ise 34 hafta +6 güne kadar tamamlanması gerekmektedir (12). Rotavirüs aşısı Amerika Birleşik Devletleri, Güney Afrika, Avusturalya, Finlandiya, Ortadoğu'da beş ülke ve Avrupa'da dört ülkede rutin aşı takviminde bulunmaktadır. Ülkemizde ise rutin bağışıklama programında yer almamaktadır $(11,13)$.

\section{Araştırmanın Amacı}

Bu çalışma Zonguldak’ta il merkezinde yaşayan 0-5 yaş arası çocuklarda rotavirüs sıklığını, anne-babaların rotavirüse yönelik bilgi düzeyleri ve uygulamalarını belirlemek amacıyla yapılmıştır.

\section{Araștırmanın Soruları}

- Zonguldak il merkezinde yaşayan 0-5 yaş arası çocuklarda rotavirüs sıklığı nedir?

- Anne-babalar çocuklarını rotavirüs enfeksiyonundan korumak için hangi uygulamaları yapmaktadır?

- Anne-babaların eğitim durumu rotavirüs ile ilgili uygulamalarını etkilemekte midir?

- Anne-babaların rotavirüsü bilme durumu aşı yaptırmalarını etkilemekte midir?

- Anne-babaların çocuklarına aşı yaptırmaları çocukların rotavirüsle karşılamalarını etkilemekte midir?

* Doç. Dr., Bülent Ecevit Üniversitesi Çocuk Sağlığı ve Hastalıkları Anabilim Dalı, Zonguldak. E-posta: tayyildiz67@hotmail.com, ORCID: 0000-00028924-5957 **Dr. Öğretim Üyesi, Bülent Ecevit Üniversitesi Halk Sağlığı Hemşireliği Anabilim Dalı, Zonguldak. ORCID: 0000-0003-4191-1559 *** Öğrenci Hemşire, Bülent Ecevit Üniversitesi Sağlık Bilimleri Fakültesi, Zonguldak. ORCID: 0000-0002-5496-8266 **** Öğrenci Hemşire, Bülent Ecevit Üniversitesi Sağlık Bilimleri Fakültesi, Zonguldak. ORCID: 0000-0002-4813-3078 ***** Öğrenci Hemşire, Bülent Ecevit Üniversitesi Sağlık Bilimleri Fakültesi, Zonguldak. ORCID: 0000-0002-7574-0690 


\section{Yöntem}

Araştırmanın Tipi

$\mathrm{Bu}$ araştırma kesitsel, tanımlayıcı tipte bir araştırmadır.

Araştırmanın Yeri ve Zamanı

Çalışma Mart- Mayıs 2019 tarihleri arasında Zonguldak il merkezinde yer alan; Bahçelievler Aile Sağlığı Merkezi (ASM), Sendika ASM, Acılık ASM, Çınartepe ASM, İnağzı ASM, Meşrutiyet ASM, Soğuksu ASM, Çaydamar ASM, Rat ASM, Mithatpaşa ASM ve Karaelmas ASM'lerinde yapılmıștır.

Araştırmanın Evren ve Örneklemi

Araştırmanın evrenini Zonguldak il merkezinde yer alan ASM'lerde takip edilen, 0-5 yaş arasında çocuğu olan 3972 anne-baba oluşturmuştur. Örneklemi ise evren bilindiği durumlarda kullanılan formul ile (\%95 güvenilirlik ve \pm \% 5 'lik sapma ile) yapılan hesaplamaya göre belirlenen 354 anne-baba oluşturmuştur. Bu sayıya ulaşılana kadar ASM'lere gelen ve araştırmaya katılmayı kabul eden anne-babalar araştırma kapsamına dahil edilmiştir.

\section{Veri Toplama Araçlart}

Veri Toplama Formu: Form, iki bölüm ve 38 sorudan oluşmaktadır. Birinci bölümde çocuğun cinsiyeti, yaşı ile ilgili bilgileri içeren beş, anne-babaların eğitim durumları, yaşları ve meslekleriyle ilgili bilgileri içeren dokuz soru bulunmaktadır. İkinci bölüm ise, araştırmacılar tarafından literatür bilgisi doğrultusunda oluşturulan $(5,8,9)$, ebeveynlerin rotavirüs ve rotavirüs aşısı hakkında bilgilerinin ve uygulamalarının yer aldığı 24 sorudan oluşmaktadır. Veri Toplama Formu hazırlandıktan sonra beş uzman görüşü alınmıştır. Uzman görüşleri sonrası formun son hali verilmiştir. Veri toplama formu yüz yüze görüşme tekniği ile uygulanmıştır. Formun doldurulması yaklaşık 10-15 dakika sürmüştür.

\section{Verilerin Değerlendirilmesi}

Araştırma verileri Statistical Package for Social Sciences (SPSS) 16.0 programında değerlendirilmiştir. Veriler aritmetik ortalama, standart sapma, ortanca, minimum-maximum, yüzde ve sayı değerleri ile gösterilmiştir. Gruplar arası yapılan karşılaştırmalarda ki kare testi $\left(\mathrm{X}^{2}\right)$ kullanılmıştır. Veriler \%95 güven aralığında değerlendirilmiştir.

Araştırmanın Etik Yönï

Araştırmanın yürütülebilmesi için Zonguldak İl Sağlık Müdürlüğü ve Zonguldak Bülent Ecevit Üniversitesi İnsan Araştırmaları Etik Kurulu'ndan (11.01.2019 tarih ve 477 nolu karar ile) izin alınmıştır. Yazılı izinler sonrası ASM'lere kayıtlı 0-5 yaş aralığındaki çocukların anne-babalarına araştırmanın amacı hakkında bilgi verilerek, sözlü izinleri alınmıştır.

\section{Çalışmanın Sınırlılıkları}

Araştırma verileri 0-5 yaş çocuğu olan anne babalarla sınırlıdır.

\section{Bulgular}

Tablo 1. Çocuğa Ait Bazı Tanımlayıcı Özelliklerin Dă̆ılımı (n=354)

\begin{tabular}{|c|c|c|c|}
\hline Özellik & $\begin{array}{c}\text { Ort. } \pm \text { SS.(min.-max.) } \\
\text { ortanca }\end{array}$ & Sayı & $\%$ \\
\hline Yaş(ay) & $\begin{array}{c}31.16 \pm 18.43(1-60) \\
\text { 30.0 } \\
\end{array}$ & & \\
\hline Çocuk sayısı & $\begin{array}{c}1.85 \pm 0.76(1-4) \\
2.0 \\
\end{array}$ & & \\
\hline Cinsiyet & $\begin{array}{c}\text { K1z } \\
\text { Erkek }\end{array}$ & $\begin{array}{l}173 \\
181 \\
\end{array}$ & $\begin{array}{l}48.9 \\
51.1 \\
\end{array}$ \\
\hline Anne Sütü Alma & $\begin{array}{l}\text { Evet } \\
\text { Hayır }\end{array}$ & $\begin{array}{c}323 \\
31\end{array}$ & $\begin{array}{c}91.2 \\
8.8\end{array}$ \\
\hline Beslenme Şekli* & $\begin{array}{c}\text { Anne sütü } \\
\text { Ek gida } \\
\text { Mama } \\
\text { Karıșık beslenme }\end{array}$ & $\begin{array}{c}124 \\
92 \\
22 \\
221\end{array}$ & $\begin{array}{c}35.1 \\
26.0 \\
6.2 \\
62.4\end{array}$ \\
\hline Kreşe Gitme & $\begin{array}{c}\text { Evet } \\
\text { Hayır }\end{array}$ & $\begin{array}{c}56 \\
298\end{array}$ & $\begin{array}{l}15.8 \\
84.2\end{array}$ \\
\hline Çocuğa Bakan Kişi & $\begin{array}{c}\text { Anne } \\
\text { Baba } \\
\text { Bakıc1 } \\
\text { Diğer** }\end{array}$ & $\begin{array}{c}269 \\
5 \\
26 \\
54\end{array}$ & $\begin{array}{c}76.1 \\
1.4 \\
7.3 \\
15.2\end{array}$ \\
\hline Tuvalet Eğitimi & $\begin{array}{l}\text { Evet } \\
\text { Hayır }\end{array}$ & $\begin{array}{l}146 \\
208\end{array}$ & $\begin{array}{l}41.2 \\
58.8\end{array}$ \\
\hline
\end{tabular}

*Anne-babalar birden fazla şık belirtmiştir. **Anneanne, babaanne, hala

Araştırmaya katılan toplam 354 katılımıının, 0-5 yaş çocuklarına ilişkin bazı tanımlayıcı özellikleri Tablo 1'de yer almaktadır. Çocukların yaş ortalaması ay olarak 31.16 \pm 18.43 (01-60) olup, \%51.1'i ( $\mathrm{n}=181)$ erkektir. Beslenme şekli olarak çocukların \%62.4'ü (n=221) karışık beslenmektedir (Tablo 1). 
Anne-babaların sahip olduğu ortalama çocuk sayısı 1.85 \pm 0.76 (1-4)'dır. Çocukların \%15.8'i (n=56) kreşe gitmekte olup, \%76.1'ine $(n=269)$ annesi bakmaktadır. Çocukların \%91.2'sinin ( eğitimini tamamlamadığı belirlenmiştir (Tablo 1).

Tablo 2. Anne-Babaların Bazı Tanımlayıcı Özelliklerinin Dağılımı (n=354)

\begin{tabular}{llcc}
\hline Özellik & & n & \% \\
\hline Anketi Cevaplayan Birey & Anne & 298 & 84.2 \\
& Baba & 56 & 15.8 \\
\hline Annenin Eğitim Durumu & İlkokul & 61 & 17.2 \\
& Ortaokul & 64 & 18.1 \\
& Lise & 131 & 37.0 \\
& Üniversite & 98 & 27.7 \\
\hline Babanın Eğitim Durumu & İlkokul & 38 & 10.7 \\
& Ortaokul & 55 & 15.6 \\
& Lise & 149 & 42.1 \\
Ailenin Gelir Düzeyi & Üniversite & 112 & 31.6 \\
& Geliri giderinden az & 124 & 35.0 \\
\hline Toplam & Geliri giderine eşit & 189 & 53.4 \\
\hline
\end{tabular}

Çalışmaya katılan bireylerin \%84.2'sini (n=298) anneler oluşturmaktadır. Anne-babaların eğitim durumuna baktığımızda annelerin \%37.0'sinin $(n=131)$, babaların ise \%42.1'inin $(n=149)$ lise mezunu olduğu belirlenmiştir. Ailelerin yarısından fazlasının (\%53.4, n=189) gelirinin giderine eşit olduğu tespit edilmiştir (Tablo 2).

Tablo 3. Anne-Babaların Hijyen Özelliklerinin Dağılımı (n=354)

\begin{tabular}{llcc}
\hline Özellik & & $\mathbf{n}$ & $\mathbf{\%}$ \\
\hline Beslenme Sirasında Hijyenik & Evet & 351 & 99.2 \\
Koşullara Dikkat Etme & Hayır & 3 & 8 \\
\hline & Evet & 46 & 13.0 \\
Çocuğun Havuza Girme Durumu & Hayır & 308 & 87.0 \\
\hline & Evet & 352 & 99.4 \\
Tuvalet Hijyenine Dikkat Etme & Hayır & 2 & 6 \\
\hline & Yıkamam & 106 & 29.9 \\
& Ara sıra & 135 & 38.2 \\
Tuvaletten Önce El Yıkama & Çoğunlukla & 67 & 18.9 \\
& Her zaman & 46 & 13.0 \\
\hline & Ara sıra & 6 & 1.7 \\
Tuvaletten Sonra El Yıkama & Çoğunlukla & 131 & 37.0 \\
Toplam & Her zaman & 217 & 61.3 \\
\hline
\end{tabular}

Anne babaların \%99.2'si (n=351) beslenme sırasında hijyenik koşullara dikkat ettiğini, \%99.4'ü (n=352) tuvalet hijyenine dikkat ettiğini, \%38.2'si (n=135) tuvalet öncesinde ara sıra ellerini yıkadığını, \%61.3'ü (n=217) tuvalet sonrasında ise her zaman ellerini yıkadığını belirtmiştir. Çocukların \%87'sinin $(n=308)$ son bir yıl içinde toplu alanlarda bulunan havuzlara girmediği görülmüştür (Tablo 3).

Anne babaların \%35.9'u (n=127) çocuklarının daha önce gastroenterit geçirdiğini, \%15.5'i (n=55) rotavirüs ile enfekte olduğunu belirtirken; \%84.5'i (n=299) rotavirüs ile enfekte olmadığını ifade etmiştir. Anne-babaların \%27.7'si (n=98) rotavirüs aşısı yaptırdıklarını belirtmişlerdir. Anne-babalar aşı yaptırmama nedenlerini, \%35.1'i ( $\mathrm{n}=124)$ aşıyı duymama, \%12.7'si (n=45) aşının koruyuculuğuna inanmama, \%11.9'u (n=42) maddi olanaksızlık, \%6.8'i (n=24) yan etkileri olduğunu düşünme, \%5.9’u (n=21) uygun aşılama zamanını kaçırma olarak ifade etmişlerdir. 
Tablo 4. Anne-Babaların Rotavirüs ve Rotavirüs Aşısı Hakkında Bilgilerinin Dağılımı (n=354)

\begin{tabular}{|c|c|c|c|}
\hline Özellik & & Sayı & $\%$ \\
\hline \multirow[t]{2}{*}{ RV Bilme } & Biliyor & 204 & 57.6 \\
\hline & Bilmiyor & 150 & 42.4 \\
\hline \multirow[t]{4}{*}{ RV Bilgi Alınan Yer $(n=204)$} & İnternet & 24 & 6.8 \\
\hline & Kurs & 2 & 0.6 \\
\hline & Sağlık Personeli & 147 & 41.5 \\
\hline & Diğer*** & 31 & 8.7 \\
\hline \multirow[t]{4}{*}{ RV Bulaşma Yolu* } & Fekal & 61 & 17.2 \\
\hline & Oral & 43 & 12.2 \\
\hline & Solunum & 38 & 10.6 \\
\hline & Temas & 149 & 42.1 \\
\hline \multirow[t]{6}{*}{ RV Tedavi* } & Alternatif & 10 & 2.9 \\
\hline & Antibiyotik & 47 & 13.3 \\
\hline & Aş1 & 39 & 11.0 \\
\hline & Serum & 108 & 30.5 \\
\hline & Siv1 & 53 & 14.9 \\
\hline & Diğer** & 37 & 10.4 \\
\hline \multirow[t]{2}{*}{ Ĕgitim Almak İsteme Durumu } & Evet & 115 & 32.5 \\
\hline & Hayır & 35 & 9.9 \\
\hline \multirow[t]{2}{*}{ RV Aşısını Bilme } & Biliyor & 181 & 51.1 \\
\hline & Bilmiyor & 173 & 48.9 \\
\hline \multirow[t]{4}{*}{ RV Aşısı Bilgi Alınan Yer $(n=181)$} & İnternet & 12 & 3.4 \\
\hline & Kurs & 1 & 0.3 \\
\hline & Sağlık Personeli & 153 & 41.2 \\
\hline & Diğer*** & 15 & 4.2 \\
\hline \multirow[t]{2}{*}{ RV Aşı Yapılma Zamanı } & Doğru & 83 & 23.4 \\
\hline & Yanlış & 98 & 27.7 \\
\hline \multirow[t]{3}{*}{ RV Aşı Dozu } & 1 & 10 & 2.8 \\
\hline & 2 & 166 & 46.9 \\
\hline & 3 & 5 & 1.4 \\
\hline \multirow[t]{2}{*}{$\overline{\text { RV Aşının Etkinliği }}$} & Evet & 154 & 43.5 \\
\hline & Hayır & 27 & 7.6 \\
\hline
\end{tabular}

* Anne-babalar birden fazla şık belirtmiştir. **Anne sütü, hijyen, istirahat. ***Çevre, akraba, arkadaşlar, yazılı kaynaklar.

Rotavirüsü bildiğini ifade eden 204 (\%57.6) anne-babanın rotavirüs hakkındaki bilgiyi nereden aldığı incelendiğinde \%41.5'inin (n=147) sağlık personelinden bilgi aldığı saptanmıştır. Rotavirüsün bulaşma yolu ve tedavisi sorgulandığında; anne-babaların \%42.1'i (n=149) temas yoluyla bulaştığını ve \%30.5’i (n=108) serum ile tedavi edildiğini ifade etmişlerdir. Rotavirüsü bilmeyen 150 (\%42.4) anne-babanın \%32.5'inin ( $\mathrm{n}=115)$ eğitim almayı istediği saptanmıştır (Tablo 4).

Rotavirüs aşısını bilen $181(\% 51.1)$ anne-babanın rotavirüs aşısı hakkında ki bilgiyi \%41.2'sinin (n=153) sağlı personelinden aldığ görülmüştür. Anne babaların, \%2.8'i (n=10) aşının bir doz yapıldığını ve \%43.5'i (n=154) aşının etkili olduğunu belirtmişlerdir (Tablo 4).

Tablo 5. Annelerin Eğitim Durumuna Göre Rotavirüs Enfeksiyonunu, Rotavirüs Aşısını Bilme ve Aşı Yaptırma Değişkenlerinin Karşılaştırılması

\begin{tabular}{|c|c|c|c|c|c|c|}
\hline \multirow[t]{2}{*}{ Değişken } & \multicolumn{4}{|c|}{ Ĕgitim Durumu } & \multicolumn{2}{|c|}{ Test değeri } \\
\hline & İlkokul n (\%) & Ortaokul n (\%) & Lise n (\%) & Üniversite n (\%) & $\mathrm{X}^{2}$ & $\mathbf{p}$ \\
\hline \multicolumn{7}{|l|}{$\overline{\text { RV Bilme }}$} \\
\hline Evet & $17(27.9)$ & $26(40.6)$ & $78(59.5)$ & $83(84.7)$ & 60.917 & .001 \\
\hline Hayır & $44(72.1)$ & $38(59.4)$ & $53(40.5)$ & $15(15.3)$ & & \\
\hline \multicolumn{7}{|c|}{ RVAșı Bilme } \\
\hline Evet & $11(18.0)$ & $26(40.6)$ & $67(51.1)$ & $77(78.6)$ & 59.103 & .001 \\
\hline Hayır & $50(82.0)$ & $38(59.4)$ & $64(48.9)$ & $21(21.4)$ & & \\
\hline \multicolumn{7}{|c|}{ Așı Yaptırma } \\
\hline Evet & $3(4.9)$ & $11(17.2)$ & $29(22.1)$ & $55(56.1)$ & 60.917 & .001 \\
\hline Hayır & $58(95.1)$ & $53(82.8)$ & $102(77.9)$ & $43(43.9)$ & & \\
\hline Toplam & $354(100.0)$ & $354(100.0)$ & $354(100.0)$ & $35(100.0)$ & & \\
\hline
\end{tabular}


Annelerin eğitim durumuna göre rotavirüs enfeksiyonunu ( $p=.001)$, rotavirüs aşısını ( $p=.001)$ bilme ve rotavirüs aşısını yaptırma $(p=.001)$ durumları arasında istatistiksel olarak anlamlı farklılık bulunmuştur. Üniversite mezunu olan annelerin (\%84.7) rotavirüs enfeksiyonunu, (\%78.6) rotavirüs aşısını bilme ve (\%56.1) rotavirüs aşısını yaptırma oranları diğer öğrenim grubundaki annelerden anlamlı şekilde yüksek olduğu görülmüştür.

Tablo 6. Anne-Babaların Rotavirüs Aşısını Yaptırma Durumuna Göre Rotavirüs Aşısını Bilme ve Çocukların Rotavirüs Enfeksiyonu Geçirme Değişkenlerinin Karşılaştırılması

\begin{tabular}{|c|c|c|c|c|}
\hline \multirow[t]{2}{*}{ Değişken } & \multicolumn{2}{|c|}{ RV Așısını Yaptırma } & \multicolumn{2}{|c|}{ Test değeri } \\
\hline & Evet n (\%) & Hayır n (\%) & $\mathbf{X}^{2}$ & $\mathbf{p}$ \\
\hline \multicolumn{5}{|l|}{ RV Bilme } \\
\hline Bilen & $95(96.9)$ & $86(33.6)$ & 1.138 & .001 \\
\hline Bilmeyen & $3(3.1)$ & $170(66.4)$ & & \\
\hline \multicolumn{5}{|c|}{ RV Geçirme } \\
\hline Olan & $18(18.4)$ & $37(14.5)$ & .827 & .363 \\
\hline Olmayan & $80(81.6)$ & $219(85.5)$ & & \\
\hline Toplam & $98(100.0)$ & $256(100.0)$ & & \\
\hline
\end{tabular}

Anne-babaların rotavirüs aşısını bilme ve yaptırma durumları arasında istatistiksel olarak anlamlı farklılık görülmüştür $(p=.001)$. Rotavirüs aşısını bilen anne-babaların, rotavirüs aşını yaptırma oranları bilmeyen anne babalardan anlamlı şekilde yüksek bulunmuştur. Rotavirüs aşısını bilenlerin \%96.9’u aşıyı yaptırırken, bilmeyenlerin \%3.1'i aşıyı yaptırmıştır. Anne-babaların çocuklarına rotavirüs aşısı yaptırma durumu ile çocukların rotavirüs geçirmeleri arasında istatistiksel olarak anlamlı farklılık bulunmamıştır ( $\mathrm{p}>.05)$.

\section{Tartışma}

Zonguldak il merkezinde yaşayan ve çalışma kapsamına alınan, 0-5 yaş grubu çocuklarda gastroenterit geçirme oranı \%35.9, rotavirüs ile karşılaşma oranı ise \%15.5 olarak belirlenmiştir. Çocuklarda viral gastroenteritlerin en önemli nedeni rotavirüslerdir. Ülkemizde yapılan farklı çalışmalarda, rotavirüs enfeksiyonu sıklığının \%10.3-20.3 (3,14, 15,16) arasında değiştiği saptanmıştır. Araştırmada tespit edilen rotavirüs enfeksiyonu görülme sıklığı literatürle uyumludur.

Çalışmaya katılan anne-babaların \%57.6'sının rotavirüs, \%51.1'inin rotavirüs aşısı hakkında bilgi sahibi olduğu saptanmıştır (Tablo 4). Çıklar ve Güner (2020) yaptıkları çalışmada, rota aşısının annelerin en çok bildikleri ücretli aşılardan biri olduğunu ifade etmişlerdir (17). Köksal ve Köksal (2012) 2010 ve 2011 yıllarında bir aile sağl1 merkezine başvuran ve dört ayını bitirmiş bebeği olan anne-babalarla yaptığı çalışmalarında; anne babaların 2010 yılında \%19.2'sinin, 2011 yılında ise \%24.8'inin rotavirüs aşısı ve hastalık hakkında bilgi sahibi oldukları tespit edilmiştir (18). Bu çalışma bulgularına benzer şekilde son yıllarda anne-babaların rotavirüs aşısını bilme oranlarının önceki yıllarda yapılan çalışmalara göre yüksek olduğu görülmüştür $(17,18)$. Bu durumun son yıllarda rotavirüs aşısının daha fazla önerilmesine ve yaygınlığının artmasına bağlı olabileceği düşünülmektedir.

Anne-babaların, \%27.7'sinin rotavirüs aşısını yaptırdığı görülmektedir. Yapılan çalışmalarda rotavirüs aşıS1 yaptırma oranının düşük olduğu görülmüştür (20,21,22). Bülbül ve arkadaşları (2013) çalışmalarında rotavirüs aşısı yaptırma oranını \%.007 ( $\mathrm{n}=8)$ olarak tespit etmişlerdir. Bunlardan altısının bir dozu, ikisinin iki dozu yaptırdığını belirlemişlerdir (19). Bu çalışmada rotavirüs aşısının uygulama oranının düşük olmasına rağmen önceki yıllarda yapılan çalışmaya göre daha yüksek olduğu görülmüştür. Bu durumun son yıllarda aşının yaygınlığının artmasına bağlı olabileceği düşünülmektedir.

Çalışmada rotavirüs aşısı yaptırmama sebeplerine bakıldığında; anne babalar ilk üç sırada aşıyı duymama, aşının koruyuculuğuna inanmama ve aşıyı yaptırmama nedenini bilmeme olarak ifade etmişlerdir. Kaçmaz Ersü ve arkadaşları (2016) çalışmalarında anne-babalar büyük oranda, (\%81.1) rotavirüs aşısını duymadıkları için çocuklarına aşı yaptırmadıklarını ifade etmişlerdir. Aynı çalışmada diğer aşı yaptırmama nedenleri maddi olanaksızlık, aşının koruyuculuğuna inanmama, uygun aşılama zamanını kaçırma ve aşının yan etkilerinin olduğunu düşünme olarak ifade edilmiştir (22). Aşı hakkında bilgi sahibi olan anne-babaların aşı yaptırmama nedenlerinin incelendiği başka bir çalışmada ise; aşıya güvensizlik ve maliyetin yüksek oluşunun ilk sıralarda yer almakta olduğu görülmüştür (18). Araştırmada aşı yaptırmamanın en sık nedeni aşıyı duymama olarak ifade edilmiştir. Bu durum Kaçmaz Ersü ve arkadaşlarının (2016) çalışması ile uyumludur.

Anne-babaların rotavirüs enfeksiyonu ve rotavirüs aşısı hakkında bilgi kaynaklarının en yüksek oranda sağlık personeli olduğu, bunu çevre, akraba, arkadaşlar, yazılı kaynaklar ve internetin izlediği tespit edilmiştir (Tablo 4). Yapılan çalışmalarda da bu araştırmaya benzer şekilde aşılar hakkında bilginin yüksek oranda sağlık personelinden alındığı belirlenmiştir $(17,20)$.

Rotavirüs aşısını bilen 181 (\%51.1) anne-babanın aşının uygulandığı ayı \%27.7'sinin yanlış, \%23.4'ünün doğru bildiği belirlenirken; aşının yapılma dozunu, \%2.8'inin bir doz olarak ifade ettikleri görülmüştür (Tablo 4). Ülkemizde uygulanan iki marka rotavirüs aşısı mevcuttur. Bebeklere hangi aşının verildiğine bağlı olarak iki veya üç doz aşı uygulanmaktadır. Aşı dozlarının uygulanması ilk doz iki aylık, ikinci doz dört aylık, üçüncü doz altı aylık (gerekirse) şeklindedir (24). Rotavirüs aşısını bildiğini düşünen anne-babaların aşı hakkında yeterli ve doğru bilgilerinin olmadığı görülmektedir.

Annelerin eğitim durumuna göre rotavirüs enfeksiyonunu, rotavirüs aşısını bilme ve rotavirüs aşısını yaptırma durumları arasında istatistiksel olarak anlamlı farklılık bulunmuştur. Üniversite mezunu olan annelerin (\%84.7) rotavirüs hastalığını, (\%78.6) rotavirüs aşısını bilme ve (\%56.1) rotavirüs aşısını yaptırma oranları diğer öğrenim grubundaki annelerden 
Araştırma

anlamlı şekilde yüksek bulunmuştur ( $p<.05$ ) (Tablo 5). Yapılan çalışmalarda da annelerin eğitim durumları ile aşıları bilme $(24,25)$, çocukların aşılanma durumları (21) arasında anlamlı farklılık olduğu belirlenmiştir. Genel olarak, çocukların aşılanma oranlarına yönelik yapılan çalışmalarda annelerin düşük eğitim düzeyinin aşılanmayı olumsuz etkilediği gösterilmiştir (21,2428). Annelerin eğitim durumu yükseldikçe rotavirüs enfeksiyonunu, rotavirüs aşısını bilme ve rotavirüs aşısını yaptırma oranlarındaki artış literatür ile uyumlu ve bekledik bir sonuçtur.

Rotavirüs aşısını bilen anne babaların, aşı yaptırma oranlarının bilmeyenlere göre anlamlı şekilde yüksek olduğu görülmüştür ( $p=.001)$. Rotavirüs aşısını bilenlerin \%96.9'u aşıyı yaptırırken, bilmeyenlerin \%3.1'i aşıyı yaptırmıştır (Tablo 6). Çalışmamıza benzer şekilde, Kaçmaz Ersü ve arkadaşları (2016) çocukların aşılanma durumlarına göre aşıyı duymadığı için aşıyı yaptırmama arasında anlamlı farklılık olduğunu belirlemişlerdir (22). Aşıyı bilmeyen ya da duymayan anne-babaların aşıyı yaptırma oranlarının düşük olması beklenen bir sonuçtur.

Anne-babaların çocuklarına rotavirüs aşısı yaptırma durumu ile çocukların rotavirüs enfeksiyonu geçirmeleri arasında istatistiksel olarak anlamlı farklılık bulunmamıştır ( $\mathrm{p}>.05)$. Yapılan ayrıntılı literatür taraması sonucu ülkemizde çocukların rotavirüs aşısı yaptırma durumlarına göre rotavirüs enfeksiyonu geçirme arasındaki ilişkiyi inceleyen çalışmaya rastlanmamıştır. Rotavirus aşısından beklenen, doğal rotavirus enfeksiyonuna benzer immun yanıt oluşturarak, orta-ciddi enfeksiyonlardan koruması, hastaneye yatışları, ölümleri önlemesi ve hastalığın süre ve şiddetini azaltmasıdır. Yapılan çalışmalarda, rotavirüs aşısının küçük çocuklarda şiddetli rotavirüs enfeksiyonuna karşı korumada etkili olduğu gösterilmiştir $(13,29,30)$. Ancak rotavirüs gastroenteritine neden olan baskın genotiplerin prevalansının ülkeden ülkeye ve yıldan yıla değiştiği bilinmektedir. Bu nedenle rotavirüs sürveyans çalışmalarının devamlılığının hem uygulanacak aşı seçiminde hem de uygulanan aşının etkinliğini ve kapsayıcılığını izlemede önemlidir $(31,32)$.

\section{Sonuçların Uygulamada Kullanımı}

Sonuç olarak, anne-babaların rotavirüs aşısını bilme durumlarının yüksek olmasına rağmen rotavirüs aşı yaptırma oranı düşük bulunmuştur. Bu durumun nedenleri aşıyı duymama, maddi olanaksızlık, aşının koruyuculuğuna inanmama olarak tespit edilmiştir. Çalışmada annelerin eğitim düzeyi arttıkça rotavirüs ve rotavirüs aşısını bilme, rotavirüs aşısını yaptırma oranlarının arttığı görülmüş olup rotavirüs aşısı yaptırma konusunda en önemli bilgilendirme kaynağının sağlık personeli olduğu saptanmıştır. Ülkemizde rotavirüs enfeksiyonlarının önlenmesinde ve hastalığa bağlı mortalite ve morbiditenin azaltılmasında aşının çok önemli rol oynadığı düşünülmektedir. Bu nedenle aile sağlığı merkezlerine gelen anne-babalara hemşirelerin rutin aşılar yapılırken rotavirüs aşısı hakkında eğitimlerin yapılması, tanıtıcı broşürlerin hazırlanması ve anne babalara verilmesi önerilebilir. Rotavirüs aşısının ülkemizde Sağlık Bakanlığı çocukluk çağı rutin aşı programında yer almasının rotavirüs aşılanma oranlarının artırılmasında en önemli etken olduğu düşünülmektedir.

\section{Bilgilendirme}

Yazarların katkı oranı beyanı şöyledir: fikir/kavram TKA; tasarım TKA, HKA ÖK; denetleme/danışmanlık TKA, HKA; veri toplama ve işleme CA, EM, TY; analiz ve yorum TKA, CA, EM, TY; kaynak taraması: CA, EM, TY; makalenin yazımı: TKA, HKA, CA, EM, TY; eleştirel düşünme: TKA, HKA, CA, EM, TY.

Araştırma ile ilgili herhangi bir projeden ya da firmadan destek alınmamıştır. Araştırmanın bütçesi araştırmacılar tarafindan karşılanmıştır.

Yazarlar arasında herhangi bir çıkar çatışması yoktur. Ayrıca sorumlu olduğumuz araştırmada herhangi bir firma ile çıkar ilişkisi bulunmamaktadır.

Araştırmanın yapılabilmesi için bir üniversitenin girişimsel olmayan araştırmalar etik kurulundan 11.01.2019 tarih 2019/477 nolu karar ile izin alınmıştır.

\section{Kaynaklar}

1. Öztürk R. Akut diyare. İ.Ü. Cerrahpaşa Tıp Fakültesi Sürekli Tıp Eğitimi Etkinlikleri. Gastrointestinal Sistem Hastalıkları Sempozyumu; 11-12 Ocak, 2001; İstanbul.

2. World Health Organization (WHO). Food, Water and Family Health: A Manual for Community Educators. For information andadditional copies of this document, please contact: Documentation Centre, Office of Global and Integrated Environmental Health. (EHG) WHO, 1211 Geneva 27, Switzerland. Erişim: 05.11.2018. https://www.who.int/water_sanitation_health/hygiene/settings/wsh9204.pdf

3. Tekin A. Mardin'deki akut gastroenteritli çocuklarda rotavirüs ve enterikadenovirüs $\quad$ sıklı̆̆ . Journal of Clinical and Experimental Investigations 2010;1(1):41-45.

4. Altındis M, Bányai K, Kalayci R, Gulamber C, Koken R, Apan T et al. Rotavirus surveillance in mid-western Turkey, 2006-2007. Central European Journal of Medicine 20105;(5):640-645.

5. İrvem A, Yücel FM, Yıldırım M, Kadanalı A, Dede B. Akut gastroenteritli çocuk hastalarda rotavirüs görülme sıklığı. Türk Mikrobiyoloji Cemiyeti Dergisi 2014;44(3):98-100.

6. Yasa O, Ergüven M, Karaca Atakan S, Çetiner N, Mısırlı T, Akkoç A. Yatarak izlenen rotavirüs vakalarımızın epidemiyolojik özellikleri ve nozokomiyal infeksiyon. Çocuk Dergisi 2009;9(3):127-130.

7. Dennehy PH, Cortese, MM, Begue RE. A case-control study to determine risk factors for hospitalization for rotavirüs gastroenteritis in US Children. J Pediatric Infect Dis Soc 2006; 25:1123-31.

8. Şafak B. Akut gastroenteritli çocuk hastalarda rotavirüs ve adenovirus sıklı̆̆ı. Acıbadem Üniversitesi Sağlık Bilimleri Dergisi 2014;5(2):121-124.

9. Var I, Çelik Ç. Salgınlara neden olan bazı gastroenterit virüslerinin irdelenmesi. The Journal of Food 2017;42(4):392404. 
Araştırma

10. Conk Z, Başbakkal Z, Bal Yılmaz H, Bolışık B. (Editörler). Pediatri Hemşireliğgi. Ankara: Akademisyen Tıp Kitapevi 2013: 122-124.

11. Kurugöl Z. Rotavirüs vaccines. Review. Turk Pediatri Ars 2007;42 (Suppl):36-42.

12. Madhi SA, Cunliffe NA, Steele D, Witte D, Kirsten M, Louw C, et al. Effect of human rotavirus vaccine on severe diarrhea in African infants. The New England Journal of Medicine 2010; 28(362):289-98.

13. Cortese MM, Parashar UD. Prevention of rotavirus gastroenteritis among infants and children: recommendations of the Advisory Committee on Immunization Practices (ACIP). Morbidity and Mortality Weekly Report: Recommendations and Reports, 2009; 58(2):1-25.

14. Özdemir M, Demircili ME, Bahadır F, Yavru S, Baysal B. İshalli hastalarda akut viral gastroenterit etkenlerinin araştırılması. Selçuk Tıp Dergisi 2013;29(3):127-130.

15. Öztaş S, Altındiş M, Aşık G, Acar S, Karagöz A, Bükülmez A, et al. Rotavirüs and adenovirüs in children with acute gastroenteritis and the molecular epidemiology of rotavirüs. Nobel Med 2016;12(1):87-93.

16. Topal İ, Çıkman A, Arslan YK, Sürücü Kara İ, Aydın Peker N, Karakeçili F. Akut gastroenteritli çocuklarda rotavirüs sıklığı. Fırat Tıp Dergisi 2019;24(1):14-17.

17. Çıklar S, Güner PD. Annelerin çocukluk çağı aşıları hakkındaki bilgi, davranış ve tutumları ve aşı reddi nedenleri: Nitel ve nicel bir araştırma. Ankara Med J 2020;(1):180-195

18. Köksal AO, Köksal T. Ankara'da ebeveynlerin rotavirüs hakkında bilgi düzeyleri ve çocukların rotavirüs aşılanma oranlar1. Gaziantep Tıp Dergisi 2012; 8(3):151-154.

19. Bülbül M, Ergüven M, Olcay Y, Tombalak NA. Sağlam çocuk polikliniğimize başvuran çocukların rutin aşı ve diğer aşıların uygulama oran ve düzeninin değerlendirilmesi. Göztepe Tıp Dergisi 2013;28(4):171-178.

20. Odabaş N, Kuzlu Ayyıldız T. Anne babaların çocukluk dönemi aşılarına yönelik bilgi ve uygulamalarının değerlendirilmesi. Med J West Black Sea 2020;4(1):7-11

21. Gencer MZ, Alıcıoğlu F, Arıca S, Arıca V. 24-72 ay çocukları olan ebeveynlerin sosyo-demografik özellikleri ve rutin dışı aşılar hakkındaki bilgi düzeyleri: Doğu-Batı karşılaştırması. Konuralp Tıp Dergisi 2015;7(3):141-145.

22. Kaçmaz Ersü N, Ersü A, Öztürk YK, Helvacı M, Öngel K. Gastroenterit tanısı ile hastanede yatan çocukların özellikleri ve ebeveynlerin rotavirüs aşısı hakkındaki bilgi düzeyleri. İzmir Dr. Behçet Uz Çocuk Hastanesi Dergisi 2016;6(3):203208.

23. The United States Department of Health \& Human Services (HHS). Rotavirus Vaccine: What You Need to Know. 2019. Erişim: 16.05.2019 https://www.immunize.org/vis/rotavirus.pdf

24. Kürtüncü M, Alkan, I, Bahadır Ö, Arslan N. Zonguldak'ın kırsal bir bölgesinde yaşayan çocukların aşılanma durumu hakkında annelerin bilgi düzeyleri. Electronic Journal of Vocational Colleges 2017; October/ Ekim: 08-17.

25. Polat Y, Tatlı S, Yavuzekinci M, Öztürk M, İpekçi NN, Yurdagül G. ve ark. Okul öncesi eğitime devam eden çocukların ailelerinin çocukluk çağı aşıları hakkındaki görüşleri. Gümüşhane Üniversitesi Sağlık Bilimleri Dergisi 2017;6(4):131137.

26. Merten S, Hilber AM, Biaggi C, Secula F, Bosch-Capblanch X, Namgya, P, Hombach J. Gender determinants of vaccination status in children: Evidence from a meta-ethnographic systematic review. PloS one 2015;10(8):23-35.

27. Taiwo L, Idris S, Abubakar A, Nguku P, Nsubuga P, Gidado S, Waziri E, et al. Factors affecting access to information on routine immunization among mothers of under 5 children in Kaduna State Nigeria, 2015. Pan Afr Med J 2017;27(1):3241.

28. Üzüm Ö, Eliaçık K, Örsdemir HH, Öncel EK. Ebeveynlerin aşı yaklaşımlarını etkileyen faktörler: Bir eğitim araştırma hastanesine ilişkin değerlendirme. Çocuk Enfeksiyon Dergisi 2019; 13(3): 144-149.

29. Angel J, Franco MA, Greenberg HB. Rotavirus vaccines: Recent developments and future considerations. Nat Rev Microbiol 2007;5(7):529-39.

30. Yoshinaga M, Phan TG, Nguyen TA, Yan H, Yagyu F, Okitsu S, Müller WE, Ushijima H. Changing distribution of group A Rotavirus G-types and genetic analysis of G9 circulating in Japan. Arch Virol 2006;151(1):183-92.

31. Cataloluk O, Iturriza M, Gray J. Molecular characterization of rotaviruses circulating in the population in Turkey. Epidemiol Infect 2005;133(4):673-8.

32. Gündeşlioğlu ÖÖ, Kocabaş E, Haytoğlu Z, Dayar GT, Çil MK, Durmaz R. Adana ilinde akut gastroenteritli çocuklarda rotavirüs prevalansı ve genotip dağılımı. Mikrobiyol Bul 2018;52(2):156-165. 